\title{
5-Hydroxytryptamine Receptor 1A
}

National Cancer Institute

\section{Source}

National Cancer Institute. 5-Hydroxytryptamine Receptor 1A. NCI Thesaurus. Code C105870.

5-hydroxytryptamine receptor $1 \mathrm{~A}(422 \mathrm{aa}, \sim 46 \mathrm{kDa})$ is encoded by the human HTR1A gene. This protein is involved in both serotonin binding and neurotransmitter-mediated signal transduction. 